\title{
Managing arbuscular mycorrhizal fungi for bioprotection: Mn toxicity
}

\author{
Isabel Brito ${ }^{a}$, Mário Carvalho ${ }^{\mathrm{a}, *}$, Luís Alho ${ }^{\mathrm{a}}$, Michael J. Goss ${ }^{\mathrm{b}}$ \\ ${ }^{a}$ Institute of Mediterranean Agricultural and Environmental Sciences (ICAAM), University of Evora, Apartado 94, 7002-554 Évora, Portugal \\ ${ }^{\mathrm{b}}$ University of Guelph, Kemptville Campus, Kemptville, Ontario KOG 1J0, Canada
}

\section{A R T I C L E I N F O}

\section{Article history:}

Received 7 June 2013

Received in revised form

11 September 2013

Accepted 16 September 2013

Available online 30 September 2013

\section{Keywords:}

Indigenous arbuscular mycorrhiza

Extraradical mycelium

Mn toxicity

Protection

Functional diversity

Triticum aestivum L. (wheat)

\begin{abstract}
A B S T R A C T
We investigated whether an intact extraradical mycelium (ERM) is more effective than other forms of propagule from indigenous arbuscular mycorrhizal fungi (AMF) in providing protection against stress to a host plant. The response of wheat (Triticum aestivum L.) to Mn toxicity was studied in a two-phase greenhouse experiment. In Phase 1, four Mn tolerant species from the natural vegetation, ranging from strongly mycotrophic to non- or weakly mycotrophic, were grown to develop different amounts of ERM. Wheat was then planted (Phase 2) with the ERM fragmented by sieving (Disturbed Treatment) or kept intact with no prior soil disturbance (Undisturbed Treatment). The growth of wheat was doubled by earlier and faster mycorrhizal colonization (AC) in the presence of an intact ERM at planting. There was a positive correlation between plant growth and the reduction of $\mathrm{Mn}$ and enhancement of $\mathrm{P}$ and $\mathrm{S}$ uptake into shoots. However, the growth of plants in undisturbed soil was significantly affected by the ERM developer species, which was not explained by differences in AC. Colonization starting from an intact ERM greatly enhanced the potential of AMF for protection against Mn toxicity. However, the degree of protection depended on the plant previously grown to develop the ERM, suggesting that there may be functional diversity within the ERM developed by mycotrophic plants of the natural vegetation.
\end{abstract}

(c) 2013 Elsevier Ltd. All rights reserved.

\section{Introduction}

Many benefits can accrue to plants from their association with arbuscular mycorrhizal fungi (AMF), depending on the environmental conditions (Gupta et al., 2000). The contribution from arbuscular mycorrhiza (AM) is greater under marginal biotic or abiotic conditions than in commercial agriculture. In natural ecosystems, the most important role of AM may be in bioprotection rather than in the acquisition of nutrients (Garg and Chandel, 2010).

The role of AMF in protecting their host against pathogens is well documented for several combinations of cultivated plants and fungal or nematode diseases (Harrier and Watson, 2004). Similarly, there is good evidence for beneficial effects of AMF in soils with different abiotic stresses, such as $\mathrm{Al}, \mathrm{Mn}$ and heavy metal toxicity (Yano and Takaki, 2005; Nogueira et al., 2007; Hall, 2002). The diversity of AMF may influence the outcomes of these interactions for both biotic (Thygesen et al., 2004; Lax et al., 2011), and abiotic stresses (Kothari et al., 1991; Oliveira et al., 2006). However, the majority of investigations fail to consider the richness of indigenous

\footnotetext{
* Corresponding author. Tel.: +351 266760800.

E-mail address: mjc@uevora.pt (M. Carvalho).
}

AM fungal communities (Whipps, 2004; Wehner et al., 2010). Nevertheless, such communities seem to exhibit a greater potential for protection (Tchabi et al., 2010). The great diversity of the microbial population present in the mycorrhizosphere (Toljander et al., 2007) also plays an important role in protecting against biotic (Neeraj and Singh, 2011; Siasou et al., 2009) and abiotic stresses (Nogueira and Cardoso, 2002). Despite the complexity of all these interactions, it is recognized that a well-established AM is crucial for an adequate degree of protection (Khaosaad et al., 2007; Garg and Chandel, 2010). The mycorrhiza must be created and be wellestablished before contact with the stressor, to achieve a high level of protection (Rufyikiri et al., 2000; Petit and Gubler, 2006; Nogales et al., 2009). However, under field conditions, when the stressor is already present in the soil, the role of AMF in protection is challenged by the time required to achieve an adequate level of AMF colonization, together with the cost associated with the largescale application of commercial inoculum (Sikora et al., 2008).

The extraradical mycelium (ERM) of mycorrhizas might be important for enhancing the roles of AM under field conditions. ERM is particularly efficacious as a propagule that even plant species usually not hosting mycorrhizal fungi can be colonized (Püschel et al., 2007). Root colonization from ERM starts earlier and develops faster than from other types of propagule (Martins and 
Read, 1997; Fairchild and Miller, 1988). Additionally, ERM formed by indigenous AMF will encompass the functional diversity of the local fungal population and its associated microbes, which is expected to be greater than that of any introduced commercial inoculum. Under agricultural systems ERM can develop on tolerant crops, cover crops (Kabir and Koide, 2000) or natural vegetation that grows before seeding susceptible crops (Brito et al., 2011). However, when different plants and fungi are grown together, AMF growth and species composition is host specific (Hart et al., 2003). Therefore the plants used to develop the ERM before the crop to be protected, could influence the final outcome. The benefits to nutrient acquisition, especially accumulation of $\mathrm{P}$, following AM colonization starting from ERM are well documented (Fairchild and Miller, 1988; Goss \& de Varennes, 2002) but no information was found in the literature about impacts on the mechanisms underpinning protection.

Manganese toxicity is associated with acid soils and with other soils that have undergone temporary waterlogging, resulting in reduced soil oxygen sufficiently to convert sparingly soluble Mn oxides to the more soluble $\mathrm{Mn}^{2+}$ form. For cereals, concentrations of $\mathrm{Mn}$ in the shoots above $100 \mathrm{mg} \mathrm{kg}^{-1}$ are considered high (Walsh and Beaton, 1973). AMF species and the associated microbial population seem to have different abilities to protect the plants against Mn toxicity (Posta et al., 1994; Nogueira and Cardoso, 2002). The mechanisms of protection are not fully understood, but a reduction of $\mathrm{Mn}$ absorption in AM colonized plants has been reported (Nogueira et al., 2004, 2007). These authors also suggested a possible interaction with enhanced $\mathrm{P}$ absorption, which could increase plant tolerance to the internal concentration of Mn. According to Goss et al., (1992) the expression of Mn toxicity can also be related to $\mathrm{Mg}$ availability, with ratios of $\mathrm{Mg}: \mathrm{Mn}$ in the soil solution above 100 allowing unimpaired growth of wheat. Therefore another possible protection mechanism of the AMF on Mn toxicity could be through an increased acquisition of Mg. However, several authors have reported that $\mathrm{Mg}$ accumulation is unaffected by mycorrhiza development (Marschner and Dell, 1994; Alloush and Clark, 2001; Cardoso et al., 2003).

We hypothesized that AM formation starting from a wellestablished intact ERM from indigenous AMF and its associated microbial population, would provide more efficacious protection to sensitive plants because AM colonization will start earlier and develops faster than colonization started from other sources of propagule, especially if developed on plants tolerant to the stressor. To test this hypothesis, we chose to work on a soil presenting Mn toxicity in sensitive plants. Toxic ions are continuously present in the soil, so susceptible plants require rapid protection after germination.

\section{Material and methods}

\subsection{Soil properties and characteristics}

A sandy loam Eutric Cambisol, known to give rise to Mn toxicity in wheat (Goss and Carvalho, 1992), was used in a two-phase pot experiment under a controlled environment. The soil was collected in the autumn from the top $20 \mathrm{~cm}$ of the headland for a long-term natural pasture at Mitra Farm of the University of Evora, Alentejo, Portugal $\left(38^{\circ} 32^{\prime} \mathrm{N} ; 08^{\circ} 00^{\prime} \mathrm{W}\right)$. Basic fertility assessment showed that the air-dried and sieved ( $4 \mathrm{~mm}$ ) soil contained $1.5 \mathrm{mg} \mathrm{P} \mathrm{kg}^{-1}$ (Olsen), $28.2 \mathrm{mg} \mathrm{K} \mathrm{kg}{ }^{-1}, 0.4 \mathrm{mg} \mathrm{N}-\mathrm{NO}_{3} \mathrm{~kg}^{-1}, 22.6 \mathrm{mg} \mathrm{Mn} \mathrm{kg}{ }^{-1}$ (DTPA - diethylenetriaminepentaacetic acid), $11 \mathrm{mg}$ OM (organic matter) $\mathrm{g}^{-1}$ and had a pH (water) of 6.0. There were 180 (most probable number - MPN) viable AMF propagules per gram of dry soil, consistent with AM formation not being limited by available propagules (Al-Karaki and Clark, 1999).

\subsection{Treatments and experimental protocols}

Two factors were studied: ERM developer species, grown in the first phase of the experiment, and the integrity of the ERM, present at the beginning of the second phase. Wheat was grown as the test plant in the second phase of the experiment (Experiment 1) because of its susceptibility to Mn toxicity and importance worldwide. The experiment was then repeated (Experiment 2).

In Phase 1, of each experiment, ERM developer species, Silene gallica L., Rumex bucephalophorus L., Lolium rigidum L. and Ornithopus compressus L., were planted in $8 \mathrm{~L}$ pots. These species are widespread throughout temperate regions, including on soils with Mn toxicity, and exhibit different levels of mycotrophy, ranging from highly mycotrophic (Lolium and Ornithopus) to very weakly (Rumex) or non-mycotrophic (Silene, negative control). An additional control treatment, in which No-Plants were allowed to grow prior to the wheat, was included to evaluate AMF colonization of wheat predominantly from spores. This treatment also acted as a control to discriminate between the effects of developer species on growth of wheat through changes in the availability of $\mathrm{Mg}, \mathrm{Mn}, \mathrm{P}$ and $\mathrm{S}$ due to plant absorption. The pots from this treatment were packed and maintained similarly to the pots with developer plants. Hereafter this control treatment is referred as "No-Plants". The ERM developer plants grew for 7 weeks to allow a good establishment of mycorrhiza and the development of an abundant ERM on the mycotrophic plants. Any weeds that emerged were removed daily from the pots by hand. Pots were kept in a greenhouse and watered approximately to field capacity $\left(0.17 \mathrm{~g} \mathrm{~g}^{-1}\right)$ by weight. The temperature control of the greenhouse only allowed regulation of the maximum temperature, which was set at $30^{\circ} \mathrm{C}$. Minimum and maximum air temperatures were recorded on a daily basis.

At the end of Phase 1, all the developer plants were killed by herbicide $\left(6 \mathrm{~mL}\right.$ per pot of a solution containing $1.3 \mathrm{~g} \mathrm{~L}^{-1}$ of glyphosate as Roundup ${ }^{\circledR}$ Supra $^{\mathrm{TM}}$ ). To ensure that the herbicide was not a factor in the experiment, it was also applied to the pots of the No-Plants treatment.

In Phase 2 of each experiment, the level of integrity of the ERM (Factor 2) was achieved by mechanical disturbance of the soil (fragmented ERM, Disturbed treatment) in half of the pots, with the remaining pots being left undisturbed (intact ERM, Undisturbed treatment). In the Disturbed treatment, the shoots of the ERM developer plants were excised and the soil was removed from each pot as two layers of approximately $0.2 \mathrm{~m}$ depth and passed separately through a $4 \mathrm{~mm}$ sieve. All root material separated on the sieve was cut into $2 \mathrm{~cm}$ long segments and mixed into the soil of the appropriate layer. Soil was repacked in the pots and arranged in the same two layers. Shoot material was left intact on the soil surface. In the Undisturbed treatment, the shoots of the ERM developer were also excised and left on the soil surface to ensure that transfer of assimilates from shoots was not a factor in the experiment.

Wheat (Triticum aestivum L., var. Ardila) was chosen as the test host plant. Six wheat seedlings were planted, thinned to three plants after ten days. Wheat plants grew for 540 degree-days (base temperature $0{ }^{\circ} \mathrm{C}$ ), corresponding to 21 days in Experiment 1 and 35 days in Experiment 2. Live ERM developer plants were never present during the wheat growth phase of these experiments as they were fully susceptible to the herbicide or disturbance treatments. The only nutrient applied was $\mathrm{N}$, to rule out any possible effects of Ornithopus (a legume) or soil disturbance on $\mathrm{N}$ availability to the wheat. The rate applied was $15 \mathrm{~mL}$ of $1 \mathrm{M} \mathrm{NH}_{4} \mathrm{NO}_{3}$ to each pot together with $100 \mathrm{~mL}$ of distilled water equivalent to $75 \mathrm{mg} \mathrm{N} \mathrm{kg}^{-1}$ dry soil. Pots were again watered to $0.17 \mathrm{~g} \mathrm{~g}^{-1}$ by weight. The purpose of watering the pots to weight was to eliminate the possibility of temporary waterlogging and hence the further enhancing of $\mathrm{Mn}^{2+}$ ions in the soil solution. Given the sieving of soil in the 
Table 1

Growth of ERM developer plant (dry matter) and mycorrhizal colonization (AC) (\% of root length) after seven weeks. Results are the average for the two experiments.

\begin{tabular}{lllll}
\hline Weed & Shoot $(\mathrm{g} / \mathrm{pot})$ & Root $(\mathrm{g} / \mathrm{pot})$ & Total $(\mathrm{g} / \mathrm{pot})$ & $\mathrm{AC}(\%)$ \\
\hline Silene & 3.97 & $0.34 \mathrm{~b}$ & 4.37 & $0 \mathrm{c}$ \\
Rumex & 3.97 & $0.39 \mathrm{~b}$ & 4.40 & $2 \mathrm{c}$ \\
Lolium & 3.32 & $0.51 \mathrm{a}$ & 3.90 & $51 \mathrm{~b}$ \\
Ornithopus & 3.46 & $0.26 \mathrm{~b}$ & 3.75 & $74 \mathrm{a}$ \\
\hline
\end{tabular}

Values in the same column followed by different letters are significantly different from each other $(p \leq 0.05)$. Values in columns without letters are not significantly different $(p>0.05)$.

Disturbed treatment, the Undisturbed treatment was the more likely to be impacted by poor aeration, and this would act to increase any difference in Mn availability between these two treatments but possibly reduce any benefit to wheat from an intact ERM. Changes in soil $\mathrm{pH}$, induced in the rhizosphere by the various ERM developer plants could also affect the Mn availability, and would be indicated by a lack of uniformity of results between the Disturbed treatments.

Shoot and root dry weight; mycorrhizal colonization and concentrations of $\mathrm{Mn}, \mathrm{Mg}, \mathrm{P}$ and $\mathrm{S}$ in the shoots were measured for both ERM developer plants and wheat at the end of their specific growing period. The concentration of $\mathrm{Mn}$ in the wheat shoots was the key parameter to investigate the importance of Mn toxicity and the others nutrients other evaluated because they can interfere with the sensitivity of the plant to excess Mn. In Phase 2 of Experiment 2 an additional AC assessment was carried out for wheat using the three plants removed from each pot after 10 days. The measurements in the ERM developer plants were performed in an extra set of 5 pots per species at the end of Phase 1 ( 7 weeks). Soil solution was extracted from the pots by centrifugation according to the technique described in Goss et al., (1992) and the concentrations of $\mathrm{Mn}$ and $\mathrm{Mg}$ determined by Atomic Absorption Spectrometry.

The roots were stained with Trypan Blue and AM colonization (AC) assessed according to the magnified intersections method (McGonigle et al., 1990), considering only the presence of arbuscules. A composite plant sample of the 5 replicates of each treatment was ground and analysed for $\mathrm{P}, \mathrm{S}, \mathrm{Mg}$ and $\mathrm{Mn}$ content using an Inductively Coupled Plasma-Optical Emission Spectrometer.

\subsection{Statistical analyses}

The treatments were in factorial combination and the experimental design was a complete randomized block with 5 replicates. ANOVAs were performed based on the two factors of the study, combined over the two experiments, using a generalized linear model. ERM developer plants present in the first phase of the experiments were considered as one factor (with five levels) and the integrity of the ERM (two levels) as the second factor. Variances
Table 3

Dry weight of shoots and mycorrhizal colonization (AC) of wheat at 10 days after planting (DAP) and at the end of the experiment (Final) as the \% of root length colonized. Values for AC 10 DAP were determined only in Experiment 2. Results from the end of the growing period are the average for the two experiments.

\begin{tabular}{|c|c|c|c|c|}
\hline $\begin{array}{l}\text { ERM developer } \\
\text { species }\end{array}$ & $\begin{array}{l}\text { ERM } \\
\text { integrity }\end{array}$ & $\begin{array}{l}\text { AC (\%) } \\
10 \text { DAP }\end{array}$ & $\begin{array}{l}\mathrm{AC}(\%) \\
\text { final }\end{array}$ & $\begin{array}{l}\text { Shoot } \\
\text { (mg/plant) }\end{array}$ \\
\hline \multirow[t]{2}{*}{ No-Plants } & Undisturbed & $0.9 \mathrm{~b}$ & $26.2 \mathrm{~b}$ & $116.0 \mathrm{c}$ \\
\hline & Disturbed & $0 \mathrm{~b}$ & $12.2 \mathrm{~d}$ & $91.7 \mathrm{c}$ \\
\hline \multirow[t]{2}{*}{ Silene gallica L. } & Undisturbed & $0.7 \mathrm{~b}$ & 23.1 bc & $100.6 \mathrm{c}$ \\
\hline & Disturbed & $0.3 \mathrm{~b}$ & $11.7 \mathrm{~d}$ & $91.5 \mathrm{c}$ \\
\hline \multirow{4}{*}{$\begin{array}{l}\text { Rumex } \\
\quad \text { bucephalophorus L. } \\
\text { Lolium rigidum L. }\end{array}$} & Undisturbed & $0.4 \mathrm{~b}$ & $17.5 \mathrm{bd}$ & $98.6 \mathrm{c}$ \\
\hline & Disturbed & $0.3 \mathrm{~b}$ & $8.8 \mathrm{~d}$ & $79.4 \mathrm{c}$ \\
\hline & Undisturbed & $5.8 \mathrm{a}$ & $49.8 \mathrm{a}$ & $157.6 \mathrm{~b}$ \\
\hline & Disturbed & $0.9 \mathrm{~b}$ & $18.2 \mathrm{bd}$ & $83.6 \mathrm{c}$ \\
\hline \multirow{2}{*}{$\begin{array}{l}\text { Ornithopus } \\
\quad \text { compressus L. }\end{array}$} & Undisturbed & $7.3 \mathrm{a}$ & $56.4 \mathrm{a}$ & $252.7 \mathrm{a}$ \\
\hline & Disturbed & $0.2 \mathrm{~b}$ & $13.5 \mathrm{~cd}$ & $93.0 \mathrm{c}$ \\
\hline
\end{tabular}

Values in the same column followed by different letters are significantly different from each other $(p \leq 0.05)$.

were equalized using a $\log _{\mathrm{e}}$ transformation, where necessary. Student-Newman-Keuls multiple range test was used to separate the means. The results from the two experiments were consistent with one another and therefore are presented as the average of Experiments 1 and 2 .

\section{Results}

\subsection{Growth and nutrient accumulation in ERM developer plants}

The shoot and total biomass of the ERM developer species did not indicate any significant differences between treatments (Table 1). Compared with other developer species, Lolium had a significantly greater root biomass at the end of Phase 1. Mycorrhizal colonization (AC) was significantly different between developer species, with Ornithopus having the largest value, although there were no significant differences between Silene and Rumex, consistent with Silene being non-mycotrophic plant and Rumex having only residual AC (Table 1 ). The accumulation of $P$ was similar in the shoots of all developer plants but S, Mg and Mn uptake varied, with Rumex and Silene having the greatest S and Mg content and Silene containing the largest amount of Mn (Table 2). The concentrations of $\mathrm{Mg}$ and $\mathrm{Mn}$ in the soil solution at the end of Phase 1 after the growth of the ERM developer species were greatest in the NoPlants treatment, but the ratio of the two ions was significantly larger after Lolium than after other species (Table 2).

\subsection{AMF colonization of wheat roots and effects on shoot growth and nutrient accumulation}

In Phase 2, no significant differences were identified between levels of mycorrhizal colonization or the dry weight of wheat in plants from the Disturbed treatment, irrespective of the Developer

Table 2

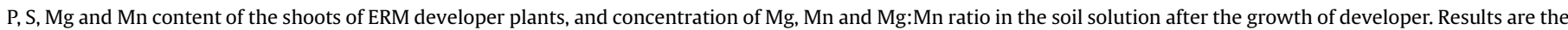
average for the two experiments.

\begin{tabular}{|c|c|c|c|c|c|c|c|}
\hline \multirow[t]{2}{*}{ ERM developer species } & \multicolumn{4}{|c|}{ Shoot content } & \multicolumn{3}{|c|}{ Concentration in soil solution } \\
\hline & $\mathrm{P}(\mathrm{mg} / \mathrm{pot})$ & $\mathrm{S}$ (mg/pot) & $\mathrm{Mg}(\mathrm{mg} / \mathrm{pot})$ & $\operatorname{Mn}(\mu \mathrm{g} / \mathrm{pot})$ & $\mathrm{Mg}(\mathrm{mg} / \mathrm{L})$ & $\operatorname{Mn}(\mathrm{mg} / \mathrm{L})$ & Ratio Mg:Mn \\
\hline No-Plants & - & - & - & - & $13.5 \mathrm{a}$ & $2.8 \mathrm{a}$ & $4.8 \mathrm{c}$ \\
\hline Silene gallica $\mathrm{L}$. & 10.3 & $15.4 \mathrm{a}$ & $22.7 \mathrm{a}$ & 1021 a & $5.8 \mathrm{~b}$ & $0.7 \mathrm{~b}$ & $8.4 \mathrm{~b}$ \\
\hline Rumex bucephalophorus L. & 9.7 & $12.1 \mathrm{~b}$ & $22.8 \mathrm{a}$ & $438 \mathrm{~b}$ & $3.6 \mathrm{c}$ & $0.3 \mathrm{c}$ & $11.9 \mathrm{~d}$ \\
\hline Lolium rigidum $\mathrm{L}$. & 6.6 & $9.0 \mathrm{c}$ & $10.1 \mathrm{~b}$ & $427 \mathrm{~b}$ & $2.4 \mathrm{c}$ & $0.1 \mathrm{~d}$ & $19.4 \mathrm{a}$ \\
\hline Ornithopus compressus L. & 9.0 & $9.8 \mathrm{bc}$ & $12.0 \mathrm{~b}$ & $280 \mathrm{~b}$ & $7.1 \mathrm{~b}$ & $0.73 \mathrm{~b}$ & $9.7 \mathrm{~b}$ \\
\hline
\end{tabular}

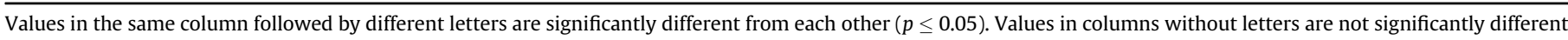
$(p>0.05)$. 
Table 4

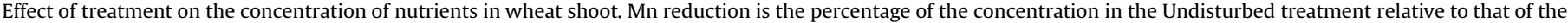
Disturbed treatment. Results are the average for the two experiments.

\begin{tabular}{|c|c|c|c|c|c|c|}
\hline ERM developer species & Soil disturbance & $\mathrm{P}\left(\mathrm{g} \mathrm{kg}^{-1}\right)$ & $\mathrm{S}\left(\mathrm{g} \mathrm{kg}^{-1}\right)$ & $\operatorname{Mg}\left(\mathrm{g} \mathrm{kg}^{-1}\right)$ & $\operatorname{Mn}\left(\mathrm{mg} \mathrm{kg}^{-1}\right)$ & Mn reduction \% \\
\hline \multirow[t]{2}{*}{ No-Plants } & Undisturbed & $1.5 \mathrm{~b}$ & $2.9 \mathrm{~b}$ & 1.8 & 179 bc & \multirow[t]{2}{*}{$26 \mathrm{c}$} \\
\hline & Disturbed & $1.0 \mathrm{~b}$ & $1.9 \mathrm{c}$ & 2.0 & $245 \mathrm{a}$ & \\
\hline \multirow[t]{2}{*}{ Silene gallica $\mathrm{L}$. } & Undisturbed & $1.2 \mathrm{~b}$ & $2.8 \mathrm{~b}$ & 1.5 & $154 \mathrm{c}$ & \multirow[t]{2}{*}{$21 \mathrm{~d}$} \\
\hline & Disturbed & $1.0 \mathrm{~b}$ & $2.4 \mathrm{bc}$ & 1.7 & $196 \mathrm{bc}$ & \\
\hline \multirow[t]{2}{*}{ Rumex bucephalophorus L. } & Undisturbed & $1.2 \mathrm{~b}$ & $2.7 \mathrm{~b}$ & 1.7 & $166 \mathrm{bc}$ & \multirow[t]{2}{*}{$20 \mathrm{~d}$} \\
\hline & Disturbed & $0.9 \mathrm{~b}$ & $2.4 \mathrm{bc}$ & 1.8 & $208 \mathrm{~b}$ & \\
\hline \multirow[t]{2}{*}{ Lolium rigidum $\mathrm{L}$. } & Undisturbed & $2.3 \mathrm{a}$ & $3.5 \mathrm{a}$ & 1.5 & $112 \mathrm{~d}$ & \multirow[t]{2}{*}{$36 \mathrm{~b}$} \\
\hline & Disturbed & $1.0 \mathrm{~b}$ & $2.4 \mathrm{bc}$ & 2.5 & $172 \mathrm{bc}$ & \\
\hline \multirow[t]{2}{*}{ Ornithopus compressus L. } & Undisturbed & $2.52 \mathrm{a}$ & $3.8 \mathrm{a}$ & 1.5 & $107 \mathrm{~d}$ & \multirow[t]{2}{*}{$47 \mathrm{a}$} \\
\hline & Disturbed & $1.02 \mathrm{~b}$ & $2.5 \mathrm{bc}$ & 1.7 & 199 bc & \\
\hline
\end{tabular}

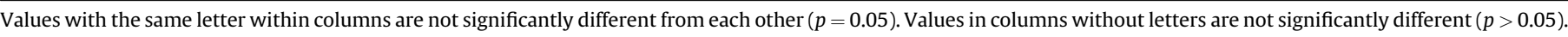

treatment (Table 3). In the Undisturbed treatment AC for wheat was significantly greater than in the Disturbed treatment. There was also a significant interaction between the ERM developer species and soil disturbance treatment with respect to AC at both sampling times and for the dry weight of wheat shoots (Table 3 ). This interaction resulted from a marked negative effect of soil disturbance on both parameters of wheat development after Lolium and Ornithopus. The significantly larger AC of wheat after Ornithopus and Lolium in the Undisturbed treatment was already established by 10 days after planting (DAP) (Table 3 ). Although there was no significant difference in the colonization parameters of wheat roots between Undisturbed treatments of Ornithopus and Lolium, the shoot growth of the wheat was much greater after the former than the latter. The difference in growth of wheat between Ornithopus and Lolium was greater ( $95.1 \mathrm{mg} /$ plant) than that between Lolium and the No-Plants treatments ( $41.6 \mathrm{mg} /$ plant). For all the other developers, including the No-Plants treatment, soil disturbance did not significantly affect the growth of the wheat (Table 3 ).

In wheat following Ornithopus or Lolium in undisturbed soil there were no significant differences between the two treatments in the concentrations of P, S and Mn in the shoots. However, the concentrations of $\mathrm{P}$ and $\mathrm{S}$ following Ornithopus or Lolium in undisturbed soil were significantly greater and the concentration of Mn significantly smaller than in all other treatments. The concentration of Mg was not affected by treatment (Table 4).

There were significant interactions between the two factors, ERM developer species and the integrity of the ERM, in the concentration of $\mathrm{P}$ and $\mathrm{S}$ in the wheat shoots (Table 4). The interactions resulted from the much greater increase in the concentration of these nutrients in the Undisturbed treatment following the growth of Ornithopus and Lolium than after the other ERM developer

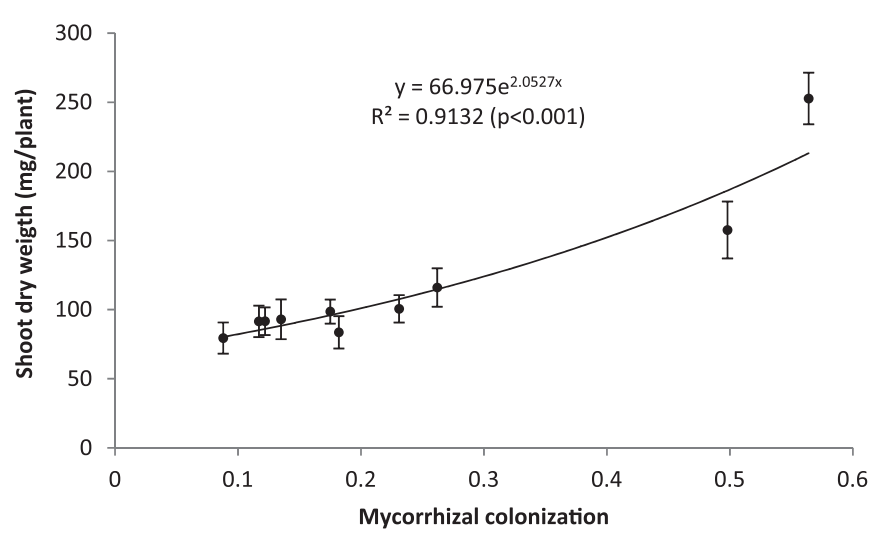

Fig. 1. Relationship between mycorrhizal colonization and shoot dry weight of wheat at end of the experiment. Values are the mean for Experiment 1 and Experiment 2. species. In contrast, the concentration of $\mathrm{Mn}$ in the shoots of the wheat decreased more in the Undisturbed treatment after Ornithopus and Lolium than after the other ERM developers, although the change following Lolium was similar to that when no developer was grown. This effect was even more evident when the reduction of $\mathrm{Mn}$ shoot concentration in the Undisturbed treatment was calculated as a percentage of its value in the disturbed treatment (Table 4).

By the end of Phase 2 of the experiment, shoot growth in wheat was directly related to AC (Fig. 1). In contrast, the Mn concentration of the shoots was inversely related to AC (Fig. 2). The concentrations of both P and S increased directly with AC (Fig. 3). Consequently, although shoot growth was inversely proportional to the Mn concentration (Fig. 4) it increased exponentially with concentration of P or S (Fig. 5).

There was a significant interaction between ERM developer species and the integrity of the ERM in the accumulation of P and S, with the shoot content being greater after Ornithopus and Lolium than after No-Plants, Silene and Rumex in the Undisturbed treatment. The accumulation of $\mathrm{P}$ and $\mathrm{S}$ by wheat after Ornithopus was almost double that after Lolium in undisturbed soil (Table 5).

\section{Discussion}

At the end of Phase 1, the period of development of the ERM, there was a large difference in AC between Ornithopus and Lolium on the one hand and Silene and Rumex on the other, consistent with there being a considerable difference in the level of ERM between these two groups of developer species. This met the objective for

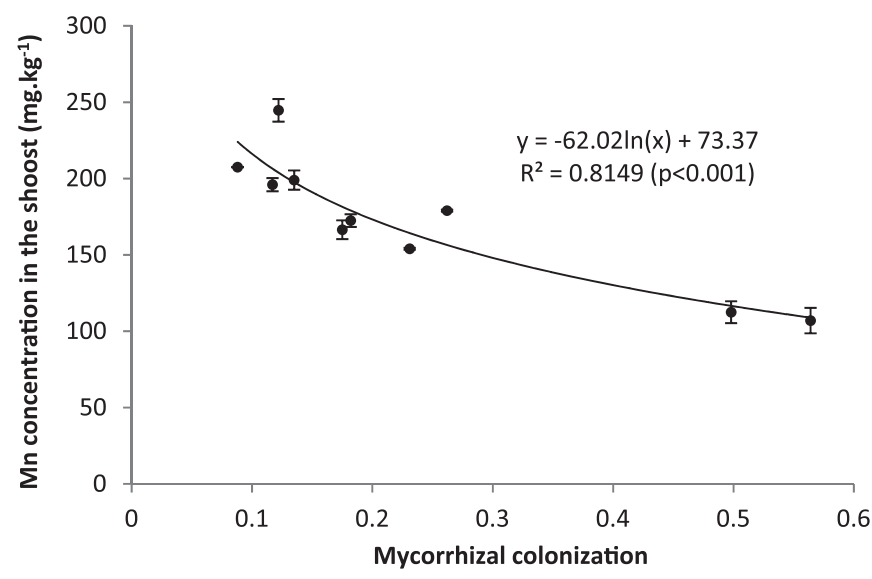

Fig. 2. Relationship between mycorrhizal colonization and Mn concentration in the shoots of the wheat at end of the experiment. Values are the mean for Experiment 1 and Experiment 2. 


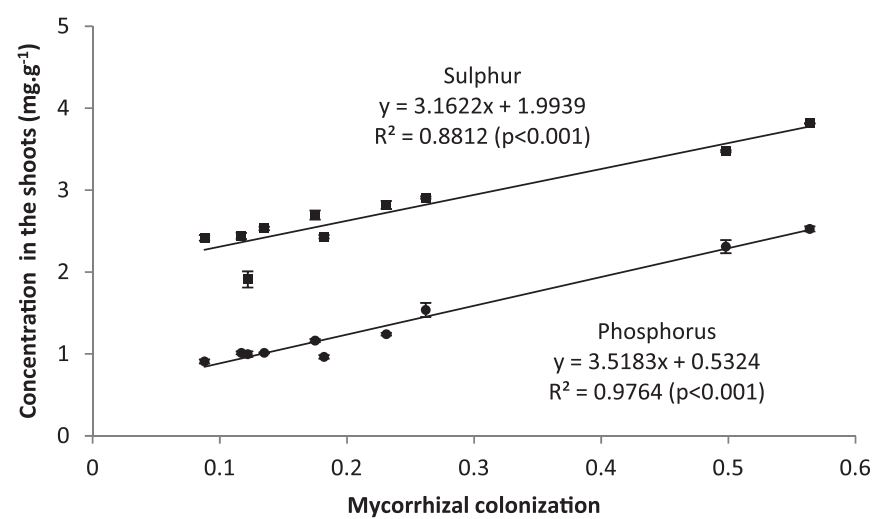

Fig. 3. Relationship between mycorrhizal colonization and $P$ and $S$ concentration in the shoots of the wheat at end of the experiment. Values are the mean for Experiment 1 and Experiment 2.

Phase 1 of the experimental procedure. Although Lolium had a significantly smaller AC than Ornithopus, when assessed on the proportion of root length colonized, it had a much greater root mass. Given that root mass is roughly proportional to root length, it seems reasonable to assume that the amount of ERM available to colonize wheat was similar after these two species, as confirmed by the AC of wheat after these two treatments in undisturbed soil.

The accumulation of $\mathrm{P}$ and $\mathrm{S}$ by the ERM developers was large, and therefore, for Phase 2 of the experiment, it was reasonable to expect that there would be somewhat more $\mathrm{P}$ and $\mathrm{S}$ available to wheat in the No-Plants treatment than in the other treatments, which would be similar to each other. Similarly, the amount of Mn and $\mathrm{Mg}$ available to wheat at planting was largest in the No-Plants treatment, although the ratio of Mg:Mn was greatest after Lolium. The similarity in growth and mycorrhizal colonization of wheat in the Disturbed treatment, whatever the preceding ERM developer species (including the No-Plant treatment), indicates that localized rhizosphere values for availability of Mn were not enhanced by root induced changes in $\mathrm{pH}$ or by temporary waterlogging. Furthermore, the better growth of wheat after Ornithopus than the other developer species in the Undisturbed treatment cannot be attributed to different levels of $\mathrm{Mn}$ or to a larger Mg:Mn ratio in the soil solution. Importantly, the Mg:Mn ratio in all treatments was well below the threshold recommended for wheat Goss et al. (1992).

The presence of an intact ERM (Undisturbed treatment after Ornithopus and Lolium) gave rise to earlier and faster AC of the wheat, confirming its greater ability to initiate AM colonization, compared with spores in large numbers (No-Plants treatment) or

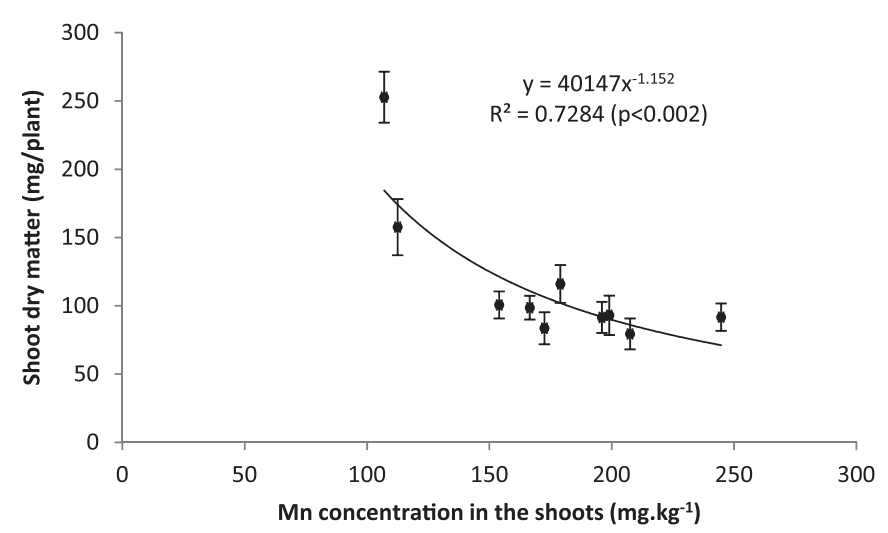

Fig. 4. Relationship between Mn concentration and dry weight of wheat shoots at end of the experiment. Values are the mean for Experiment 1 and Experiment 2.

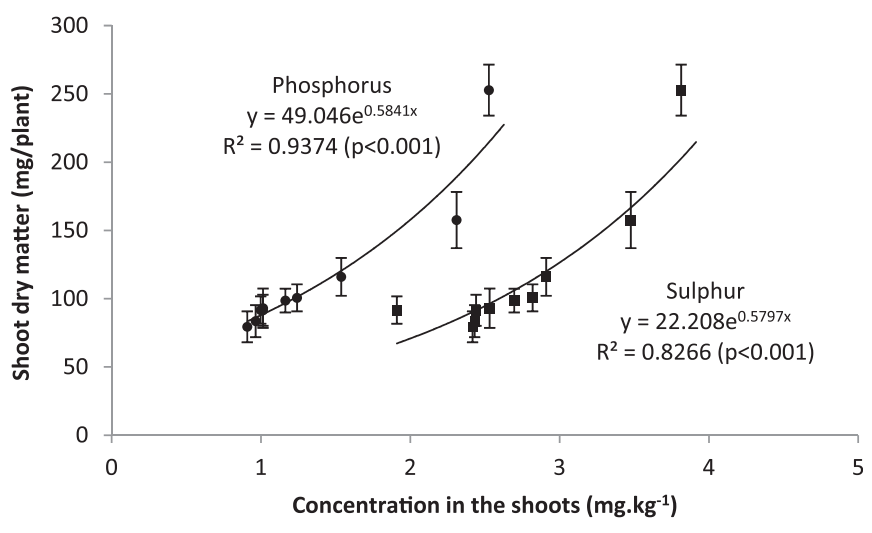

Fig. 5. Relationship between $P$ and $S$ concentration and dry weight of wheat shoots end of the experiment. Values are the mean for Experiment 1 and Experiment 2.

with spores and colonized root fragments (Disturbed treatment after Ornithopus, Lolium and Rumex) (Martins and Read, 1997; Fairchild and Miller, 1988). Wheat is not considered to be a strongly mycotrophic crop, but the levels of AC observed in roots from the Undisturbed treatment at the end of both experiments (21 DAP in Experiment 1 and 35 DAP in Experiment 2) after Ornithopus and Lolium are relatively large, supporting the concept of enhanced potential for AM colonization by an intact ERM of plants commonly considered to have a low level of mycotrophy (Püschel et al., 2007).

Our results clearly indicate that AM colonization can protect wheat against Mn toxicity, confirming earlier findings (Nogueira and Cardoso, 2002). However, in our study the protection depended on the presence of an intact ERM when wheat was sown. Nonetheless, the protective mechanism operated when the stressor was already present in the soil before the test plant was sown and did not depend on any external inoculation with AMF. As the amount of available AMF propagules in the soil used in this study was large ( 180 spores $\mathrm{g}^{-1}$ dry soil at the beginning of the experiment plus colonized root fragments or intact ERM), the results establish that it was the type of propagule and not the amount that made the difference. An intact ERM, developed previously in the soil by indigenous AM fungi, was the preferable AM propagule for crop colonization and this approach overcame the limitations usually associated with the use of AM in bioprotection (Sikora et al., 2008). There was an early and rapid AM colonization of the test host plant, considered a key factor for an adequate protection (Khaosaad et al., 2007; Garg and Chandel, 2010), and importantly the functional diversity of indigenous AM fungal and its associated microbial populations was conserved (Wehner et al., 2010; Tchabi et al., 2010). Moreover it seems possible to manage the functional

Table 5

Effect of treatments on the content of $\mathrm{P}$ and $\mathrm{S}$ in wheat shoots. Results are the average for the two experiments.

\begin{tabular}{llll}
\hline ERM developer species & Soil disturbance & $\mathrm{P}(\mathrm{mg} / \mathrm{plant})$ & $\mathrm{S}(\mathrm{mg} / \mathrm{plant})$ \\
\hline No-Plants & Undisturbed & $0.19 \mathrm{c}$ & $0.34 \mathrm{c}$ \\
& Disturbed & $0.09 \mathrm{~d}$ & $0.18 \mathrm{~d}$ \\
Silene gallica L. & Undisturbed & $0.12 \mathrm{~d}$ & $0.28 \mathrm{~cd}$ \\
\multirow{2}{*}{ Rumex bucephalophorus L. } & Disturbed & $0.09 \mathrm{~d}$ & $0.22 \mathrm{~cd}$ \\
& Undisturbed & $0.11 \mathrm{~d}$ & $0.26 \mathrm{~cd}$ \\
Lolium rigidum L. & Disturbed & $0.07 \mathrm{~d}$ & $0.19 \mathrm{~d}$ \\
\multirow{2}{*}{ Ornithopus compressus L. } & Undisturbed & $0.36 \mathrm{~b}$ & $0.55 \mathrm{~b}$ \\
& Disturbed & $0.08 \mathrm{~d}$ & $0.20 \mathrm{~d}$ \\
& Undisturbed & $0.64 \mathrm{a}$ & $0.96 \mathrm{a}$ \\
& Disturbed & $0.09 \mathrm{~d}$ & $0.23 \mathrm{~cd}$
\end{tabular}

Values with the same letter within columns are not significantly different from each other $(p=0.05)$. 
diversity of the indigenous population, by choosing the plants to be used for the development of the ERM, before the crop planting.

In our experiments the use of Ornithopus to establish an intact ERM significantly increased wheat growth relative to that following Lolium even though the level of AC in the wheat was similar. This suggests that the AMF species associated with these two plant species differed in their abilities to respond to Mn toxicity and protect the wheat. This is also consistent with there being a certain degree of host specificity (Hart et al., 2003). Further research is required to establish whether species diversity is responsible for any of these differences.

The P absorption by wheat, where AM colonization started from an intact ERM, was significantly increased in relation to the other treatments, and the growth of wheat was also significantly enhanced. The benefits to $\mathrm{P}$ absorption associated with colonization starting from an intact ERM have been reported by other authors (Fairchild and Miller, 1988; Goss \& de Varennes, 2002). However, in relation to the No-Plants treatment the magnitude of this benefit was unexpected, because no soil P depletion had taken place in the absence of plants. The enhanced absorption of $\mathrm{P}$ might be involved in the protection mechanism against Mn toxicity (Nogueira et al., 2004, 2007). However, if P absorption was a primary factor explaining the protection against Mn toxicity, better growth of wheat would have been expected in the No-Plants treatment, where $\mathrm{P}$ availability in the soil after Phase 1 was greatest, than after Silene or Rumex, as AM colonization started from a similar type of propagule and gave rise to the same level of AC. Furthermore, the concentration of $P$ in the shoots of wheat after Lolium and Ornithopus in undisturbed soil was similar but there was a large difference in the growth between these two treatments. In addition, the effects of the various treatments on the concentration and content of $S$ in wheat shoots and plant growth were very similar to those observed for P. Hence, our results indicate that the increased absorption of $\mathrm{P}$ was more a consequence of the release from Mn toxicity than the mechanism of the protection.

Despite the differences in $\mathrm{AC}$ of wheat roots, $\mathrm{Mg}$ concentration in shoots of wheat was not affected by any of the treatments. This is consistent with the findings of Marschner and Dell (1994), Alloush and Clark (2001) and Cardoso et al. (2003). Thus, Mg absorption by wheat was not involved in the protection against Mn toxicity by AM colonization starting from an intact ERM.

A reduction in Mn concentration in the shoots was clearly a factor in alleviation of toxicity in wheat. When comparing results for treatments starting with the four developer species, colonization starting from an intact ERM (Undisturbed treatments of Lolium and Ornithopus) effected a greater reduction than that from other types of propagule. However, in these experiments compared with the Disturbed treatment the concentration of $\mathrm{Mn}$ in shoots of wheat from the Undisturbed treatment was also reduced in the absence of any ERM developer plants. This may reflect greater mucilage release from roots experiencing more impedance to penetration (Bengough et al., 2011). However, the reduction in tissue concentration of wheat shoots as a percentage of that in shoots from disturbed soil was greatest when the AM colonization started from an intact ERM (Lolium and Ornithopus) and importantly values decreased to around $100 \mathrm{mg} \mathrm{Mn} \mathrm{kg}{ }^{-1}$, which is considered the lower limit for toxic concentrations of $\mathrm{Mn}$ in cereals (Walsh and Beaton, 1973). Despite the absolute differences in the concentration of $\mathrm{Mn}$ in the shoots of the wheat between Disturbed and Undisturbed treatment within each developer, when the AM colonization started from an intact ERM (Lolium and Ornithopus in undisturbed soil), the relative reduction in the internal concentration of $\mathrm{Mn}$ in comparison to the disturbed treatment was significantly greater than for the other treatments, and more important its values decrease to around $100 \mathrm{mg} \mathrm{Mn} \mathrm{kg}{ }^{-1}$, considered as the limit for high values of the internal concentration of Mn in cereals (Walsh and Beaton, 1973). Therefore the earlier and faster AM colonization of the wheat achieved in those two treatments were crucial to grant protection of the wheat against excessive $\mathrm{Mn}$, and this was reflected in the significantly greater growth of the plants. AMF reduces Mn absorption in colonized plants (Nogueira et al., 2004, 2007), but it is recognized that a well-established AM is crucial for an adequate degree of protection (Khaosaad et al., 2007; Garg and Chandel, 2010). In the treatments, where AM colonization started from sources of propagules other than an intact ERM, the internal concentration of $\mathrm{Mn}$ in the shoots of the wheat was still related to the level of mycorrhization but the protection was not fast enough to avoid damage of the plants and the consequent reduction of the growth. Nevertheless, the considerable difference in growth between wheat following Lolium and Ornithopus in undisturbed soil cannot be explained by the small variation in Mn concentration in the shoots. There must be other factors involved in the protection against Mn toxicity being provided by an intact ERM and the contrast between that developed on Lolium with that on Ornithopus. The latter suggests that there may be functional diversity in the indigenous AMF population that can be discriminated by the association with different ERM developer species.

The results presented in this study support our working hypothesis that AM colonization starting from an intact ERM greatly enhances the potential of AMF in protection against a stressor present in the soil at the time of sowing a crop. This approach has the advantage of assuring an early and fast AM colonization, from an indigenous well adapted AM fungal population, which can be developed by tolerant species present in natural vegetation or elements of the agricultural crop rotation and the ERM kept intact, using appropriate tillage.

\section{Conclusions}

AMF colonisation preferential starting from an intact ERM starts earlier and develops faster than from others source of inoculum and this greatly enhances the role of AMF in protecting against Mn toxicity of sensitive plants like wheat. The ERM can be developed from the native AMF by previously growing a Mn tolerant mycotrophic plant. The plant used to previously develop the ERM has a significantly effect on the degree of protection achieved, suggesting a functional diversity within the native AMF population.

\section{Acknowledgements}

This work was financed by National Funds through FCT Foundation for Science and Technology, in the frame of the project PTDC/AGR-PRO/111896/2009. The authors thank to Filipa Santos, Manuel Figo and Rodrigo Abreu for their technical assistance and FERTIPRADO for providing the seeds of the developer plants.

\section{References}

Alloush, G.A., Clark, R.B., 2001. Maize response to phosphate rock and arbuscular mycorrhizal fungi in acidic soil. Commun. Soil Sci. Plant Anal. 32, 231-254.

Al-Karaki, G.N., Clark, R.B., 1999. Varied rates of mycorrhizal inoculum on growth and nutrient acquisition by barley grown with drought stress. Commun. Soil Sci. Plant Anal. 22, 1775-1784.

Bengough, A.G., McKenzie, B.M., Hallett, P.D., Valentine, T.A., 2011. Root elongation, water stress, and mechanical impedance: a review of limiting stresses and beneficial root tip traits. J. Exp. Bot. 62, 59-68.

Brito, I., Carvalho, M., Goss, M.J., 2011. The importance of no-till in the development of cropping systems to maximize benefits of arbuscular mycorrhiza symbiosis. In: Elizabeth Stockdale, E., Watson, C. (Eds.), Proceedings of the Association of Applied Biologist "Making Crop Rotations Fit for the Future", Aspects of Applied Biology, vol. 113, pp. 137-141. 
Cardoso, E.J.B.N., Navarro, R.B., Nogueira, M.A., 2003. Changes in manganese uptake and translocation by mycorrhizal soybean under increasing Mn doses. Rev. Bras. Cienc. Solo 27, 415-423.

Fairchild, G.L., Miller, M.H., 1988. Vesicular-arbuscular mycorrhizas and the soildisturbance-induced reduction of nutrient absorption in maize II. Development of the effect. New Phytol. 110, 75-84.

Garg, N., Chandel, S., 2010. Arbuscular mycorrhizal networks: process and functions. A review. Agron. Sustain. Dev. 30, 581-599.

Goss, M.J., Carvalho, M.J.G.P.R., 1992. Manganese toxicity: the significance of magnesium for the sensitivity of wheat plants. Plant Soil 139, 91-98.

Goss, M.J., de Varennes, A., 2002. Soil disturbance reduces the efficacy of mycorrhizal associations for early soybean growth and $\mathrm{N}_{2}$ fixation. Soil Biol. Biochem. 34, 1167-1173.

Goss, M.J., Carvalho, M.J.G.P.R., Cosimini, V., Fearnhead, M.L., 1992. An approach to the identification of potentially toxic concentrations of manganese in soils. Soil Use Manag. 8, 40-44.

Gupta, V., Satyanarayana, T., Garg, S., 2000. General aspects of mycorrhiza. In: Mukerji, K.G., Chamola, B.P., Singh, J.E. (Eds.), Mycorrhizal Biology. Kluwer Academic/Plenum, pp. 27-44.

Hall, J.L., 2002. Cellular mechanisms for heavy metal detoxification and tolerance. J. Exp. Bot. 53, 1-11.

Harrier, L.A., Watson, C.A., 2004. The potential role of arbuscular mycorrhizal (AM) fungi in the bioprotection of plants against soil-borne pathogens in organic and/or other sustainable farming systems. Pest Manag. Sci. 60, 149-157.

Hart, M.M., Reader, R.J., Klironomos, J.N., 2003. Plant coexistence mediated by arbuscular mycorrhizal fungi. Trends Ecol. Evolut. 18, 418-423.

Kabir, Z., Koide, R.T., 2000. The effect of dandelion or a cover crop on mycorrhiza inoculum potential, soil aggregation and yield of maize. Agric. Ecosyst. Environ. 78, 167-174.

Khaosaad, T., Garcia-Garrido, J.M., Steinkellner, S., Vierheilig, H., 2007. Take-all disease is systemically reduced in roots of mycorrhizal barley plants. Soil Biol. Biochem. 39, 727-734.

Kothari, S.K., Marschner, H., Romheld, V., 1991. Effect of a vesicular arbuscular mycorrhizal fungus and rhizosphere microorganisms on manganese reduction in the rhizosphere and manganese concentrations in maize (zea-mays 1). New Phytol. 117, 649-655.

Lax, P., Becerra, A.G., Soteras, F., Cabello, M., Doucet, M.E., 2011. Effect of the arbuscular mycorrhizal fungus Glomus intraradices on the false root-knot nematode Nacobbus aberrans in tomato plants. Biol. Fertil. Soils 47, 591-597.

McGonigle, T.P., Miller, M.H., Evans, D.G., Fairchild, G.L., Swan, J., 1990. A new method which gives an objective measure of colonization of roots by vesiculararbuscular mycorrhizal fungi. New Phytol. 115, 495-501.

Marschner, H., Dell, B., 1994. Nutrient-uptake in mycorrhizal symbiosis. Plant Soil 159, 89-102.

Martins, M.A., Read, D.J., 1997. The effects of disturbance on the external mycelium of arbuscular mycorrhizal fungi on plant growth. Pesqui. Agropecu. Bras. 32, 1183-1189.

Neeraj, Singh, K., 2011. Organic amendments to soil inoculated arbuscular mycorrhizal fungi and Pseudomonas fluorescens treatments reduce the development of root-rot disease and enhance the yield of Phaseolus vulgaris L. Eur. J. Soil Biol. 47, $288-295$
Nogales, A., Aguirreolea, J., María, E.S., Camprubí, A., Calvet, C., 2009. Response of mycorrhizal grapevine to Armillaria mellea inoculation: disease development and polyamines. Plant Soil 317, 177-187.

Nogueira, M.A., Cardoso, E.J.B.N., 2002. Interações microbianas na disponibilidade e absorção de manganês por soja. Pesqui. Agropecu. Bras. 37, 1605-1612.

Nogueira, M.A., Magalhães, G.C., Cardoso, E.J.B.N., 2004. Manganese toxicity in mycorrhizal and phosphorus-fertilized soybean plants. J. Plant Nutr. 27, $141-$ 156.

Nogueira, M.A., Nehls, U., Hampp, R., Poralla, K., Cardoso, E.J.B.N., 2007. Mycorrhiza and soil bacteria influence extractable iron and manganese in soil and uptake by soybean. Plant Soil 298, 273-284.

Oliveira, R.S. Castro, P.M.L., Dodd, J.C., Vosatka, M., 2006. Different native arbuscula mycorrhizal fungi influence the coexistence of two plant species in a highly alkaline anthropogenic sediment. Plant Soil 287, 209-221.

Petit, E., Gubler, W.D., 2006. Influence of Glomus intraradices on black foot disease caused by Cylindrocarpon macrodidymum on Vitis rupestris under controlled conditions. Plant Dis. 90, 1481-1484.

Posta, K., Marschner, H., Römheld, V., 1994. Manganese reduction in the rhizosphere of mycorrhizal and nonmycorrhizal maize. Mycorrhiza 5, 119-124.

Püschel, D., Rydlova, J., Vosatka, M., 2007. The development of arbuscular mycorrhiza in two simulated stages of spoil-bank succession. Appl. Soil Ecol. 35, 363369.

Rufyikiri, G., Declerck, S., Dufey, J.E., Delvaux, B., 2000. Arbuscular mycorrhizal fungi might alleviate aluminium toxicity in banana plants. New Phytol. 148 $343-352$.

Siasou, E., Standing, D., Killham, K., Johnson, D., 2009. Mycorrhizal fungi increase biocontrol potential of Pseudomonas fluorescens. Soil Biol. Biochem. 41, 13411343.

Sikora, R.A., Pocasangre, L., zum Felde, A., Niere, B., Vu, T.T., Dababat, A.A., 2008. Mutualistic endophytic fungi and in-planta suppressiveness to plant parasitic nematodes. Biol. Control 46, 15-23.

Tchabi, A., Coyne, D., Hountondji, F., Lawouin, L., Wiemken, A., Oehl, F., 2010 Efficacy of indigenous arbuscular mycorrhizal fungi for promoting white yam (Dioscorea rotundata) growth in West Africa. Appl. Soil Ecol. 45, 92100.

Thygesen, K., Larsen, J., Bødker, L., 2004. Arbuscular mycorrhizal fungi reduce development of pea root-rot caused by Aphanomyces euteiches using oospores as pathogen inoculum. Eur. J. Plant Pathol. 110, 411-419.

Toljander, J.F., Lindahl, B.D., Paul, L.R., Elfstrand, M., Finlay, R.D., 2007. Influence of arbuscular mycorrhizal mycelial exudates on soil bacterial growth and community structure. FEMS Microbiol. Ecol. 61, 295-304.

Walsh, L.M., Beaton, J.D. (Eds.), 1973. Soil Testing and Plant Analysis, Madison, WI USA., p. 491.

Wehner, J., Antunes, P.M., Powell, J.R., Mazukatow, J., Rillig, M.C., 2010. Plant pathogen protection by arbuscular mycorrhizas: a role for fungal diversity? Pedobiologia 53, 197-201.

Whipps, J.M., 2004. Prospects and limitations for mycorrhizas in biocontrol of root pathogens. Can. J. Bot. - Revue Canadienne de Botanique 82, 1198-1227.

Yano, K., Takaki, M., 2005. Mycorrhizal alleviation of acid soil stress in the sweet potato (Ipomoea batatas). Soil Biol. Biochem. 37, 1569-1572. 